\title{
Sustainability of productivity in rice-mustard sequential cropping system through integrated nutrient management for terai condition of Nepal
}

\author{
B Mishra ${ }^{1}$ and RN Chaudhary ${ }^{2}$ \\ ${ }^{1}$ Nepal Agriculture Research Council, Singhadarbar Plaza, Kathmandu \\ ${ }^{2}$ National Oilseed Research Program Nawalpur, Sarlahi
}

\begin{abstract}
In absence of suitable cropping systems in terai, seed yield of mustard is decreasing. Farmers are growing mustard crop under energy starved condition and these are main reasons for low productivity of mustard. With a view to address these issues, an experiment on sustainability of productivity in rice-mustard sequential cropping system through integrated nutrient management for terai condition of Nepal was carried at Nawalpur, Sarlahi during 2004 2006. The result revealed that rice grown with $100 \%$ recommended dose of fertilizer and 10 tons compost /ha produced a maximum mean grain yield of $4371 \mathrm{~kg} / \mathrm{ha}$ and straw yield of $5045.5 \mathrm{~kg} / \mathrm{ha}$ which might be due to maximum dry matter accumulation. Likewise, it was exhibited that application of recommended dose of fertilizer with $10 \mathrm{t}$ compost on preceding rice resulted in maximum seed yield of mustard $(1259 \mathrm{~kg} / \mathrm{ha})$. The finding also showed that mustard grown with recommended dose of fertilizer produced a maximum mean seed yield of 1384 $\mathrm{kg} / \mathrm{ha}$. There was a positive effect of these treatments on seed yield attributes and seed yield of succeeding mustard. Economic analysis for the effects of treatments resulted a maximum benefit cost (BC) ratio of 2.0 which was obtained for mustard when grown after recommended dose of fertilizer. An encouraging BC ratio of 3.45 was found when mustard was taken with $100 \%$ recommended dose of fertilize (RDF).
\end{abstract}

Key word: Sustainability, rice-mustard, sequential cropping, integrated nutrient management.

\section{Introduction}

Rapeseed and mustard are the major oilseed crops of Nepal. Of them, mustard is emerging as important oilseed crop of the country. Rice- mustard pattern is one of the major cropping patterns followed in Terai/inner Terai of the country. Mustard is also grown as inter/mixed crop with lentil, chickpea, and linseed. Yield potential of mustard is higher than tori which is highly responsive to high inputs. In terai sizeable portion of land remains fallow after harvest of rice. In the last several years, the productivity of oilseed crops remained almost stagnant and low. The problem of low yield is associated mainly with decline in soil fertility which is caused by continuous adoption of the same cropping system maize/rice/mustard. Rapeseed and mustard are energy rich crops and are being grown under energy starvation condition. This may have a direct bearing on crop response and productivity of rapeseed mustard. Some of the widely adopted cropping systems involving oilseeds may remove as much as 400 to $900 \mathrm{~kg}$ nutrients per hectare under high productivity system (Hegde', 2003). Unless the soils as replenished with the nutrients removal by the preceding crops, the persistent nutrient exhaust may pose a great threat to sustainable production of these crops.

This study addresses the problem of decline in soil fertility. The study of this cropping system involving integrated nutrient management might bring a break through for addressing low yield of mustard. Other reasons for low yield of rapeseed mustard are diseases and pests. Alternaria is causing reduction in yield 
as much as 37- $44 \%$ in mustard. Orobanche, a root parasite, has become a great threat for production. Present study will try to reduce the problem of Alternaria and Orobanche as mustard is almost resistant to Orobanche and less infested by alternaria. Therefore mustard seems one of the probable crops to be included in the study. The other problem is aphid and almost 20-30\% yield reduction is caused due to it. It is reported that mustard is less preferred by aphid compared to rapeseed (Tori). Similarly, nutrients removal by crops was generally more than supplied through chemical fertilizers and this negative balance over years led to the declining yields. This study will address most of the problems of these crops and will help increase their productivity.

Cropping system is the kind and sequence of crops grown on a given area of soil over a period of time. Cropping system should also include the principles and practices of cropping and interaction with farm re4sources, environment, regional or national needs and production strategies.

Mustard (Brassica juncea) is coming up as a new crop in many parts of the country with increase in irrigation facilities. However, productivity of mustard and other oilseed crops is low. Oil seed production often suffers from a high degree of variation in annual production owing to their predominant cultivation under low and uncertain rainfall situation as most of the area under these crops is rainfed. The situation is further handicapped by input starved conditions with poor crop management. Oilseeds are energy rich crops and obviously the requirement of major nutrient is very high. Improving efficiency and factor productivity under complexities of diminishing quantity response and increasing eco-awareness is critical for sustainable oilseed production. The judicious use of these nutrients is very important as our country is importing most of the fertilizers from aboard.Under present situation, focus on nutrient management in mustard needs to be changed from individual crop to cropping system. The low level of utilization of nutrients supplied through fertilizer calls for choosing appropriate combination of sequences of crops to utilize nutrients efficiency for long term sustainability. Therefore there is a need to pay attention to harness the residual effect of fertilizers, so that application of the nutrients can be phased to get maximum benefit.

Cropping system based approach of agriculture research does not have long history in Nepal especially oilseed based. The use of chemical fertilizers is playing a key role in crops like mustard for higher seed production. Therefore, adequate experimental information on important agronomic aspects, like selection of preceding crops for mustard based cropping systems and the nutrient management in the preceding as well as succeeding crops is essential. A study conducted by Singh et al (1998) at Sri Ganganagar to evaluate relative performance of five crops sequences at different irrigation levels revealed that green gram- Indian mustard (Brassica juncea) performed better when treated with higher frequency of irrigation. The experiment conducted by Hasan (1999) on the productivity and economics of rice (Oryza sativa) based crop sequences at mid to high altitude temperate zone of Jammu and Kashmir found that rice-mustard sequence recorded sustainable rice yield on long term basis. A two years study on integrated nitrogen management in rice mustard cropping system by Singh and Singh (2002) revealed that the residual effects of FYM alone or with organic $\mathrm{N}$ applied to rice crop had pronounced effects on succeeding mustard crop. Sharma and Jain (2002) conducted an experiment on N requirement of Indian mustard under different crop sequences in Navagaon, Rajasthan during 1994- 1997 which indicated that among the cropping systems Sesbania-Indian mustard gave the tallest plants $(202.4 \mathrm{~cm})$, higher Siliqua per plant (251.9) and seeds per Siliqua (15.9) as well as seed yield of 1596, 2311 and $1445 \mathrm{~kg} / \mathrm{ha}$ in 1994/95, 1995/96 and 1996/97, respectively. 


\section{Methodology}

The experiment was carried out in split plot design with 3 replications. Plot size for each sub plot was $4 \mathrm{x}$ $4 \mathrm{~m}$. The treatments were as follows:

\section{$\underline{\text { Rice }}$}

1. Control (0:0:0 kg NPK/ha)

2. Compost $10 \mathrm{t} / \mathrm{ha}$

3. Compost $10 \mathrm{t} / \mathrm{ha}+\mathrm{RDF}$

4. Compost $10 \mathrm{t} / \mathrm{ha}+1 / 2 \mathrm{RDF}$

5. $\operatorname{RDF}(60: 20: 20 \mathrm{~kg} \mathrm{NPK} / \mathrm{ha})$

Rice variety Hardinath -1 was planted and Mustard variety Verdan was planted.

Cost of cultivation and benefit cost ratio were calculated.

The cost of cultivation of the rice crop with recommended dose of fertilizer was Rs 20000/ha, for rice with recommended dose of fertilizer +10 ton/ha compost was Rs 23000/ha. The cost of cultivation for mustard with recommended dose of fertilizer was Rs 12000/ha.

Observations were recorded on periodical dry matter accumulation at $40 \& 80$ days and at harvest. Data on grain yield and straw yield for rice were also taken. On mustard crop observations were recorded on dry matter accumulation, number of primary and branches per plant, pant height, number of siliqua per plant, number of seeds/siliqua, 100 seed weight $(\mathrm{g})$, seed yield $\mathrm{kg} / \mathrm{ha}$ and total bio-mass production.

\section{Soil analysis result}

Table 1. Composite sample was taken and analyzed for both the years

\begin{tabular}{cccccc}
\hline Year & $\mathrm{pH}$ & $\mathrm{OM}(\%)$ & $\mathrm{N}(\%)$ & $\mathrm{P}_{2} 0_{5}(\mathrm{~kg} / \mathrm{ha})$ & $\mathrm{K}_{2} 0(\mathrm{~kg} / \mathrm{ha})$ \\
\hline $2004 / 05$ & 6.0 & 1.78 & 0.119 & 238 & 120 \\
$2005 / 06$ & 4.9 & 1.629 & 0.109 & 194 & 159 \\
\hline
\end{tabular}

Results and discussion

Effect of fertilizer and compost application on preceding rice crop

\section{Periodical dry matter accumulation}

Data on dry matter accumulation per hill was recorded at 40, 80 DAS and at harvest for rice. Two year's observation showed that maximum dry matter accumulation was recorded for the treatment compost 10 t/ha +RDF followed by $10 \mathrm{t}$ compost/ha $+50 \%$ RDF while control gave minimum DM (Fig. 1 and 2). DM accumulation was found maximum at harvest and minimum at 40 DAS. This trend was observed in both the years. Detail data has been given in the Annex 1. 

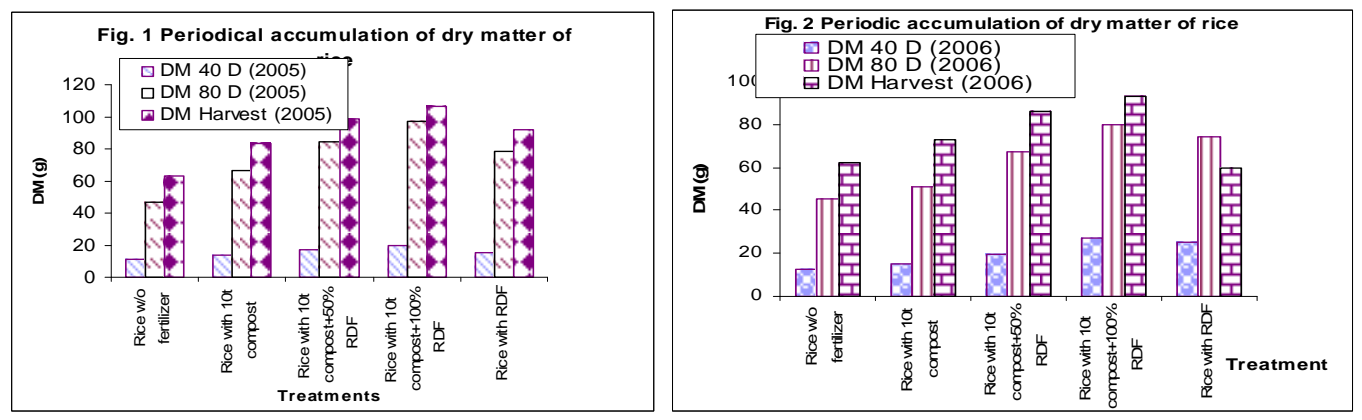

\section{Grain and straw yields}

Grain and straw yields likewise followed the same pattern which was observed for DM due to the effects of treatments in the study. The maximum grain yield of rice $4325 \mathrm{~kg} / \mathrm{ha}$ and $4417 \mathrm{~kg} / \mathrm{ha}$ in first and second year, respectively, which was recorded for treatment rice with $10 \mathrm{t}$ compost/ha $+100 \%$ RDF (Fig. 3 and 4). The same trend of straw yield was also recorded for the treatments (Fig. 3 and 4) and Annex 1. Yield increment in the treatments could be attributed due to incorporation of compost in the RDF. There is a marked response of compost that gave encouraging yield even in half dose of chemical fertilizer in the study. Rice when grown without fertilizer did not give satisfactory yield.

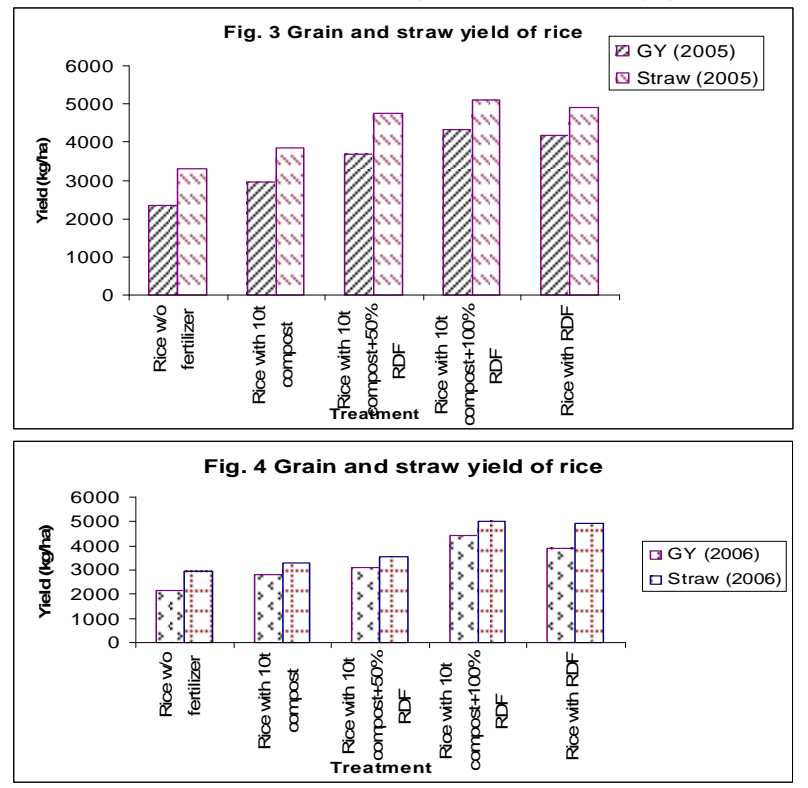




\section{Harvest index}

Harvest index (HI) for both the years were calculated and have been presented (Fig. 5). HI for both the years was around $41-47 \%$. Rice without fertilizer gave the minimum HI of $41.6 \%$ and $42.5 \%$ for the year 2005 and 2006. A maximum HI of 46.9\% was recorded for the treatment rice when grown with $10 \mathrm{t}$ compost along with $100 \%$ RDF.

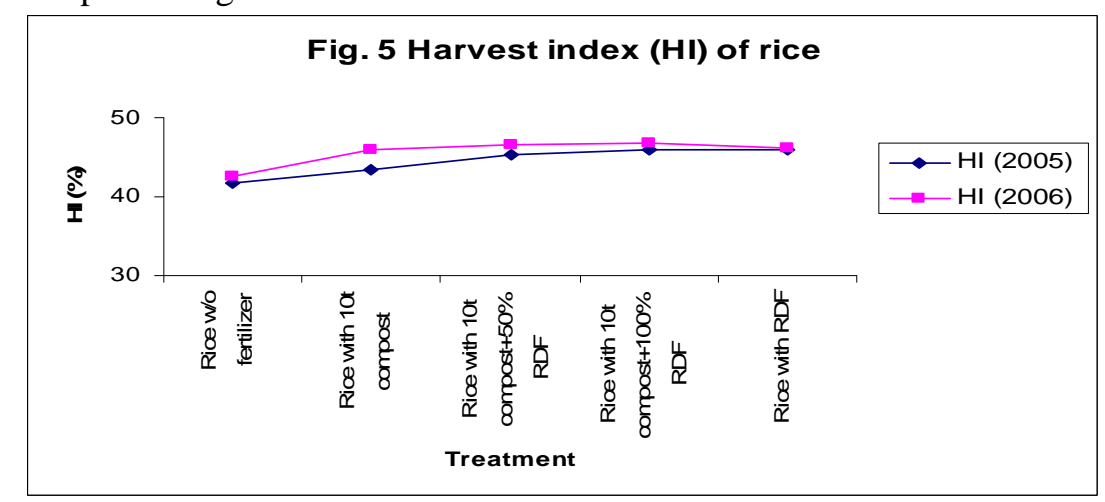

\section{Effect of preceding treatments and fertilizer levels on mustard crop}

\section{Effect on periodical dry matter accumulation}

In both the years, DM accumulation was influenced by the use of chemical fertilizer with compost. DM increment was slow up to 40 days while there a fast increase up to 80 days thereafter a slow increase was observed. In comparison with no fertilizer in preceding crops, DM accumulation was increased with chemical fertilizer (Fig. 6 and 7). The effect of chemical fertilizer on periodical DM accumulation on mustard gave significant results by increasing level fertilizer. In first year, $61.9 \mathrm{~g} \mathrm{DM} /$ plant was recorded when $100 \%$ RDF was applied to mustard crop.

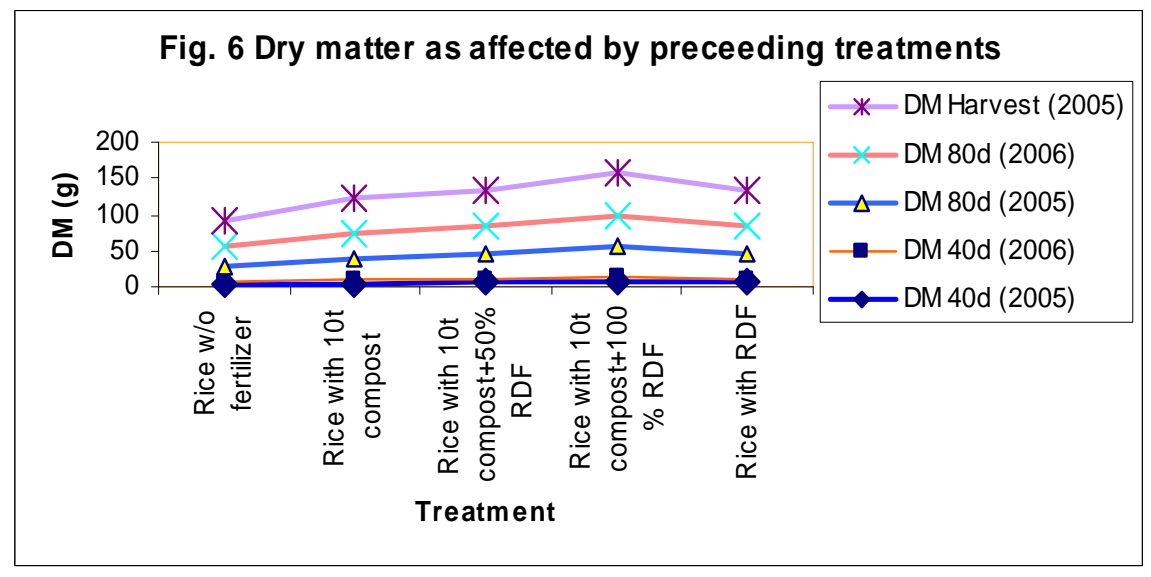




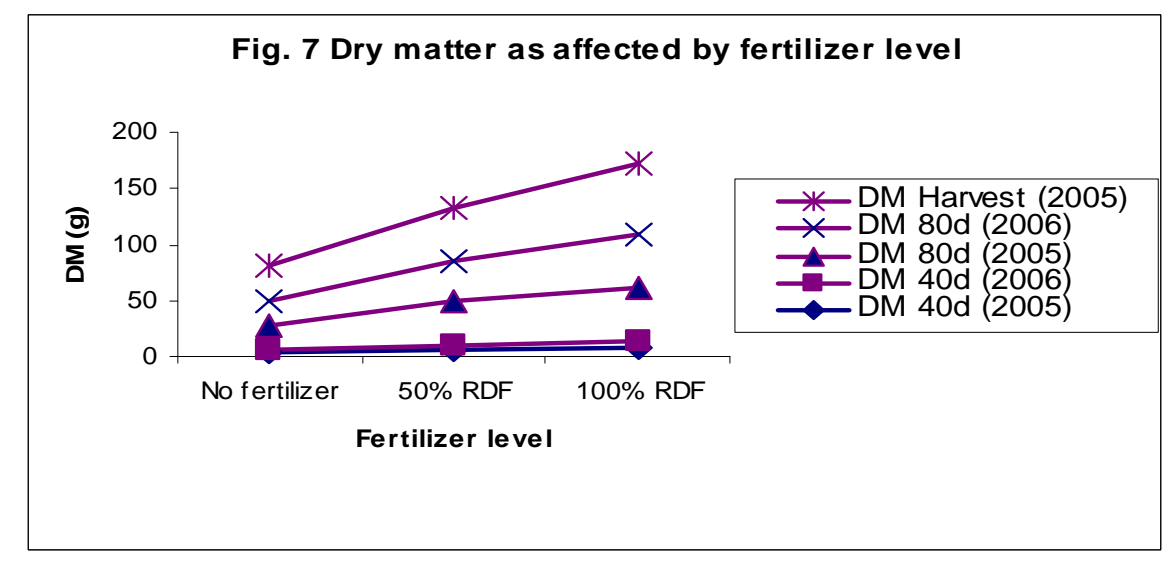

\section{Effects on agronomic components}

Data on primary branches, secondary branches and plant height were recorded (Table 1) for the year 2005 and 2006. Observation on the number of primary and secondary branches were found significant in first year while there was no significant differences in the second year (Table 1). The data on plant height for first year did not show the significant differences while in the second year it was found significant due to the effect of preceding treatments.

The effect of fertilizer application for all the agronomic characters were found significant in both the years (Table 2). The maximum number of primary branches (4.7 and 4.8) was observed when 100\% RDF was applied to mustard crop in both the years. A same trend was observed for secondary branches in both the years. Plant height of $156 \mathrm{~cm}$ and $134 \mathrm{~cm}$ was observed when $100 \%$ RDF and no fertilizer were applied in 2006. Same fashion of plant height was noticed in 2005.

Table 2. Effect of preceding treatments and fertilizer levels on yield attributing characters of mustard 2004/2005- 2005/2006, NORP, Nawalpur, Sarlahi

\begin{tabular}{|c|c|c|c|c|c|c|}
\hline \multirow[t]{2}{*}{ Treatments } & \multicolumn{3}{|c|}{$2004 / 2005$ (in gm) } & \multicolumn{3}{|c|}{ 2005/2006 (gram) } \\
\hline & $\begin{array}{c}\text { Primary } \\
\text { branch }\end{array}$ & $\begin{array}{l}\text { Secondary } \\
\text { Branch }\end{array}$ & $\begin{array}{l}\text { Plant } \\
\text { height } \\
(\mathrm{cm})\end{array}$ & $\begin{array}{l}\text { Primary } \\
\text { branch }\end{array}$ & $\begin{array}{l}\text { Secondary } \\
\text { Branch }\end{array}$ & $\begin{array}{l}\text { Plant height } \\
\quad(\mathrm{cm})\end{array}$ \\
\hline \multicolumn{7}{|c|}{ Preceding treatments } \\
\hline Rice without fertilizer: & 3.7 & 3.7 & 132 & 3.6 & 3.0 & 136.8 \\
\hline Rice with $10 \mathrm{t}$ compost & 4.0 & 4.8 & 135 & 4.2 & 3.1 & 144.9 \\
\hline $\begin{array}{l}\text { Rice with } 10 \mathrm{t} \text { compost }+ \\
50 \% \text { RDF : }\end{array}$ & 4.3 & 5.0 & 143 & 4.5 & 3.4 & 148.6 \\
\hline $\begin{array}{l}\text { Rice with } 10 \text { t compost }+ \\
100 \% \text { RDF : }\end{array}$ & 4.8 & 6.1 & 149 & 4.8 & 3.8 & 154.2 \\
\hline Rice with RDF : & 4.0 & 5.1 & 140 & 4.3 & 3.4 & 152.9 \\
\hline 'F' test & $*$ & $*$ & NS & NS & NS & $*$ \\
\hline $\mathrm{CD}(\mathrm{P}=0.05) \mathrm{kg} / \mathrm{ha}:$ & 1.1 & 1.9 & - & - & - & 7.2 \\
\hline $\mathrm{CV} \%:$ & 13.6 & 21.3 & 11 & 16.4 & 21 & 6.4 \\
\hline \multicolumn{7}{|c|}{ Fertilizer levels } \\
\hline No fertilizer : & 3.8 & 3.9 & 125 & 3.6 & 2.9 & 134.4 \\
\hline $50 \% \mathrm{RDF}$ & 4.0 & 4.3 & 145 & 4.3 & 3.7 & 145.6 \\
\hline $100 \%$ RDF: & 4.7 & 6.6 & 152 & 4.8 & 4.0 & 155.6 \\
\hline${ }^{\mathrm{a}} \mathrm{F}$ test & $*$ & $*$ & $*$ & $*$ & $*$ & $*$ \\
\hline $\mathrm{CD}(\mathrm{P}=0.05)$ : & 0.8 & 3.4 & 24 & 0.6 & 0.7 & 9.6 \\
\hline $\mathrm{CV} \%$ & 22.3 & 20.5 & 10 & 16.4 & 21 & 6.4 \\
\hline
\end{tabular}




\section{Effect on yield components}

Seeds/Siliquae, Siliqua/plant, and 1000-seed weight for both the years were recorded and presented (Table 3). The response of preceding treatments on succeeding mustarad was not significant for seeds/Siliquae and 1000-seed weight for both the years while Siliqua/plnat was significant for both the years. The maximum number of Siliqua/plant 156 and 168 was observed when rice with $10 \mathrm{t}$ compost + $100 \%$ RDF was applied in 2005 and 2006, respectively. The use of chemical fertilizers to all yield components was found significant for both the years (Table 4). The seeds/Siliquae was maximum (12.6 and 14.2) when $100 \%$ RDF was applied to mustard. Similarly, the maximum number of Siliqua/plant (168 and 174.2) was recorded for the same treatments in both the years. A 1000-seed weight of 3.9- $4.2 \mathrm{~g}$ was found when $100 \%$ recommended dose of chemical fertilizer was applied to mustard crop (Table 2).

\section{Effect on seed yield, biomass and harvest index (HI)}

Seed yield per plant, seed yield per hectare, total biomass production, and HI were recorded and presented (Fig. 8-13 and Annex 3). Seed yield/plant was significantly influenced with the prece3ding treatments. However, it was found not significant in the succeeding year. Seed yield/ha was significantly influenced with the preceding treatments for both the years. Total biomass production in 2005 was recorded significant due to the effect of preceding treatments. Seed yield/plant was maximum $20.4 \mathrm{~g}$ in 2005 while it was $21.2 \mathrm{~g}$ when mustard was taken after rice with $10 \mathrm{t}$ compost plus $100 \% \mathrm{RDF}$. The same treatment produced $1174 \mathrm{~kg}$ and $1344 \mathrm{~kg} / \mathrm{ha}$ in first and second year respectively. The maximum mean seed yield was $1259 \mathrm{~kg} / \mathrm{ha}$ for the same treatment. Total biomass production of $4315 \mathrm{~kg} / \mathrm{ha}$ and maximum HI of $26.9 \%$ was found for mustard when grown with preceding rice with $10 \mathrm{t}$ compost plus $100 \%$ RDF.

The effect of fertilizer levels on seed yield per plant of mustard crop was found highly significant in both the years. Similarly seed yield /ha was also significantly influenced by fertilizer levels. The total biomass production was also highly significant. Harvest index was also affected by different levels of fertilizer. The seed yield/plant was $21.1 \mathrm{~g}$ and $21.8 \mathrm{~g}$ when $100 \% \mathrm{RDF}$ was applied to mustard crop in first and second year. 100\% RDF when applied to mustard crop gave seed yield of $1363 \mathrm{~kg}$ and $1402 \mathrm{~kg}$ in year 2005 and 2006. The average seed yield was $1384 \mathrm{~kg} / \mathrm{ha}$ while an average seed yield of $772 \mathrm{~kg} / \mathrm{ha}$ was harvested when mustard was grown without fertilizer. The mean seed yield of $1092 \mathrm{~kg} / \mathrm{ha}$ was recorded when $50 \%$ of RDF was applied to mustard crop. The total biomass of $4843 \mathrm{~kg} / \mathrm{ha}$ and HI of $28.2 \%$ was observed when $100 \%$ RDF was applied to mustard crop.

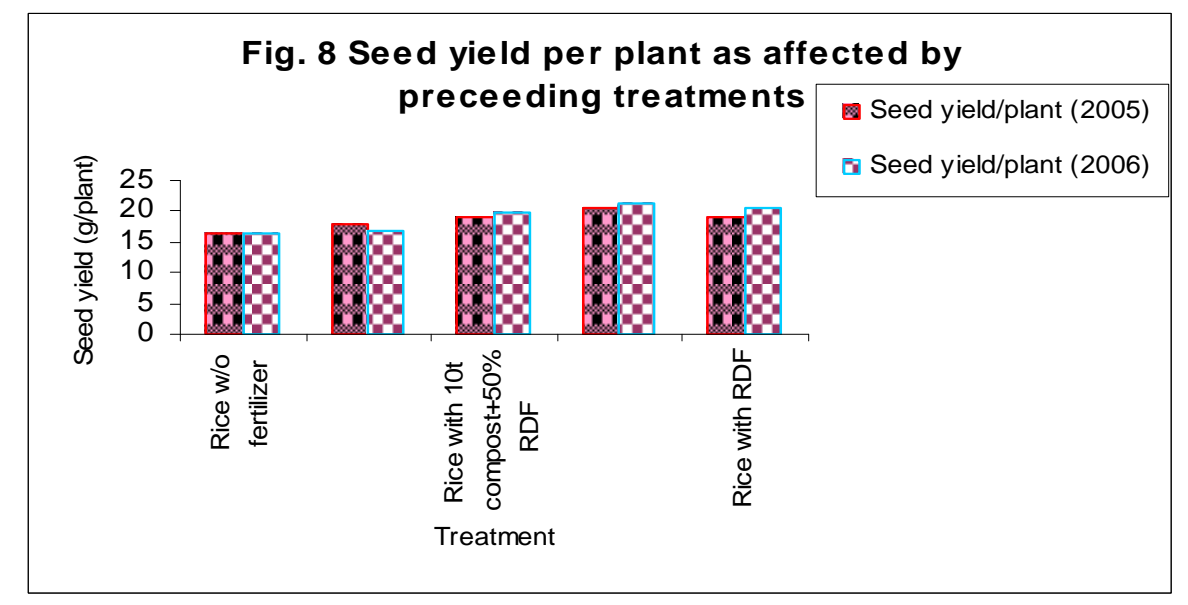


Agronomy Journal of Nepal, (Agron JN) Vol. 1: 2010
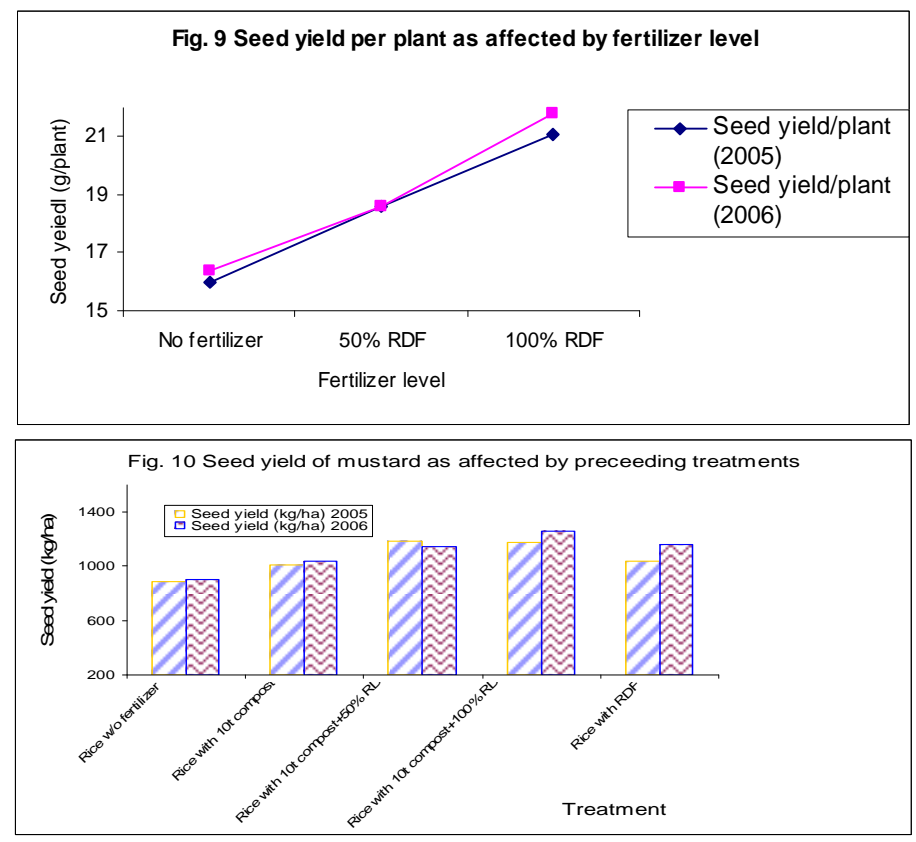

Fig. 11 Seed yield $\mathrm{kg}$ per hectare as affected by fertilizer level
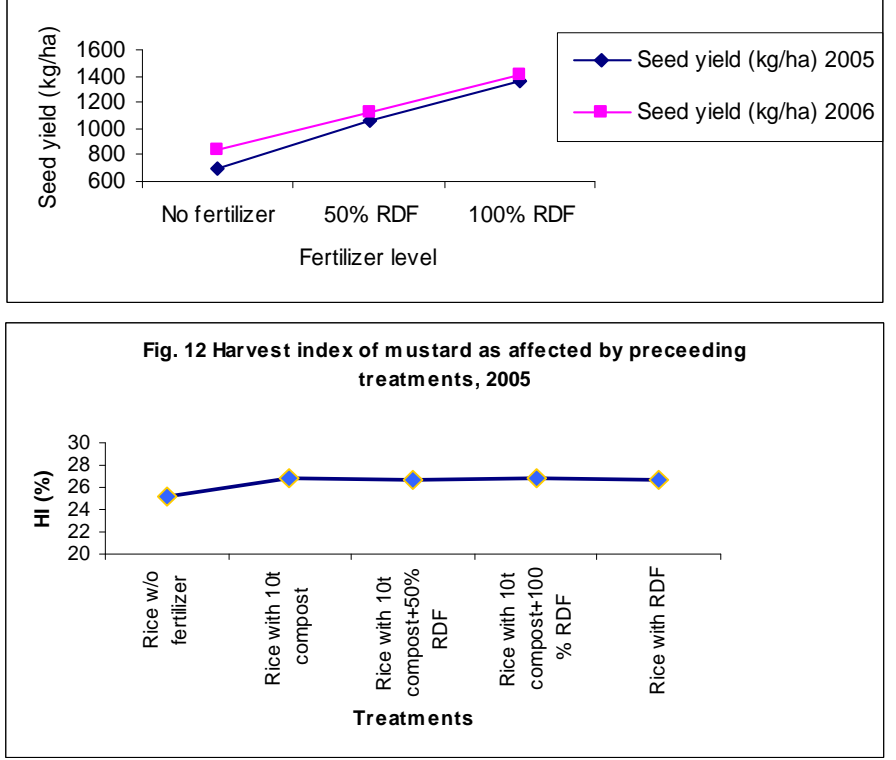


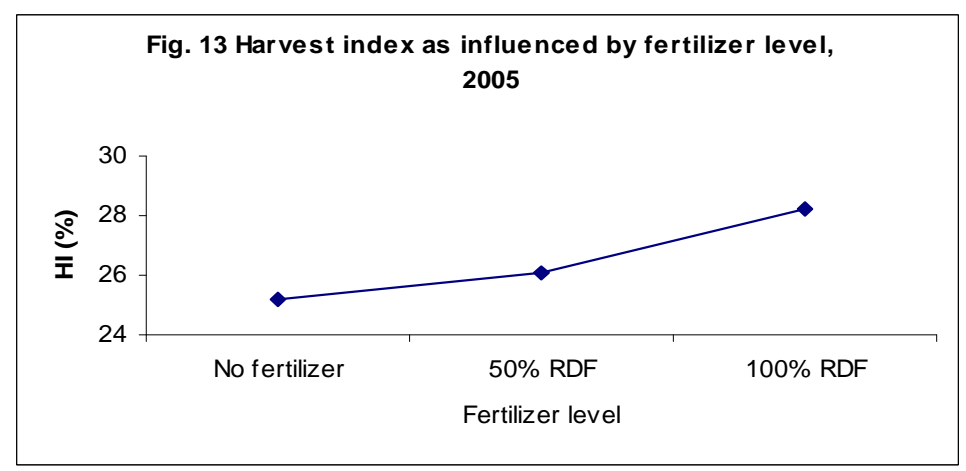

Table 3. Effect of preceding treatments and fertilizer levels on yield attributing characters of mustard, 2004/2005-2005/2006 seasons, NORP, Nawalpur, Sarlahi

\begin{tabular}{|c|c|c|c|c|c|c|}
\hline \multirow[t]{2}{*}{ Treatments } & \multicolumn{3}{|c|}{$2004 / 2005$ (in gm) } & \multicolumn{3}{|c|}{ 2005/2006 (gram) } \\
\hline & \multicolumn{2}{|c|}{ Seeds/siliquae Siliqua/plant } & \multirow{2}{*}{1000 seed wt } & \multirow{2}{*}{ Seeds/siliquae } & \multirow[t]{2}{*}{ Siliqua/plant } & \multirow[t]{2}{*}{1000 seed wt } \\
\hline Preceding Treatme & & & & & & \\
\hline $\begin{array}{l}\text { Rice without } \\
\text { fertilizer: }\end{array}$ & 11.3 & 93 & 3.8 & 9.3 & 92.2 & 3.4 \\
\hline $\begin{array}{l}\text { Rice with } 10 \mathrm{t} \\
\text { compost }\end{array}$ & 11.4 & 104 & 3.8 & 11.8 & 106.2 & 3.6 \\
\hline $\begin{array}{l}\text { Rice with } 10 t \\
\text { compost }+50 \%\end{array}$ & 12.3 & 113 & 3.9 & 12.7 & 115.2 & 4.1 \\
\hline RDF: & & & & & & \\
\hline $\begin{array}{l}\text { Rice with } 10 t \\
\text { compost }+100 \%\end{array}$ & 12.7 & 156 & 3.9 & 13.8 & 168.0 & 4.6 \\
\hline RDF : & & & & & & \\
\hline Rice with RDF : & 11.9 & 130 & 3.6 & 12.2 & 137.8 & 4.0 \\
\hline 'F' test & NS & $*$ & NS & NS & $*$ & NS \\
\hline $\mathrm{CD}(\mathrm{P}=0.05) \mathrm{kg} / \mathrm{ha}:$ & - & 33 & - & - & 12 & - \\
\hline $\mathrm{CV} \%:$ & 7.7 & 15 & 5.3 & 16.6 & 16.8 & 21 \\
\hline Fertilizer levels & & & & & & \\
\hline No fertilizer : & 11.2 & 85 & 3.7 & 10.1 & 90.8 & 3.2 \\
\hline $50 \% \mathrm{RDF}$ & 12.0 & 106 & 3.8 & 12.6 & 124.3 & 3.6 \\
\hline 100\% RDF: & 12.6 & 168 & 3.9 & 14.2 & 174.2 & 4.2 \\
\hline${ }^{\mathrm{a}} \mathrm{F}$ test & $*$ & $* *$ & $*$ & $*$ & $*$ & $*$ \\
\hline $\mathrm{CD}(\mathrm{P}=0.05)$ & 1.2 & 28 & 0.3 & 1.4 & 32 & 0.4 \\
\hline $\mathrm{CV} \%$ & 5.7 & 14 & 5.0 & 16.6 & 18.0 & 21 \\
\hline
\end{tabular}

$\mathrm{a} *, * *$, an NS indicate significant at $\mathrm{P}<0.05,0.01$ and not significant, respectively

\section{Economic analysis}

Benefit cost ration (BC) for this experiment was calculated (Table 3). Of the treatments a $\mathrm{BC}$ ratio of 2.0 was obtained when mustard was taken after fertilized rice followed by (1.9) mustard when taken after rice with $10 \mathrm{t}$ of compost plus $100 \%$ RDF. A minimum $\mathrm{BC}$ ratio of 1.33 was obtained when mustard was sown after unfertilized rice. Similarly the maximum BC ratio of 3.45 was recorded when $100 \%$ of RDF was applied to mustard crop followed by 3.24 when mustard was sown with $50 \%$ recommended dose of fertilizer (Table 4). 
Table 4. Cost of cultivation for sustainable productivity under rice-mustard sequential cropping system through integrated nitrogen management for Terai region of Nepal

\begin{tabular}{|c|c|c|c|c|c|}
\hline Treatment & $\begin{array}{l}\text { Cost of cultivation } \\
\text { (NRs) }\end{array}$ & Yield (Kg/ha) & Rate (NRs/kg) & $\begin{array}{l}\text { Gross return } \\
(\mathrm{NRs})\end{array}$ & $\mathrm{BC}$ ratio \\
\hline $\begin{array}{l}\text { Rice without } \\
\text { fertilizer: }\end{array}$ & 17000 & 2261.5 & 10 & 22616 & 1.33 \\
\hline $\begin{array}{l}\text { Rice with } 10 \mathrm{t} \\
\text { compost }\end{array}$ & 20000 & 2870.5 & 10 & 28705 & 1.43 \\
\hline $\begin{array}{l}\text { Rice with } 10 \mathrm{t} \\
\text { compost }+50 \% \\
\text { RDF : }\end{array}$ & 20500 & 3533 & 10 & 3533 & 1.55 \\
\hline $\begin{array}{l}\text { Rice with } 10 \mathrm{t} \\
\text { compost }+100 \% \\
\text { RDF : }\end{array}$ & 23000 & 4371 & 10 & 4371 & 1.9 \\
\hline $\begin{array}{l}\text { Rice with RDF : } \\
\text { Fertilizer level }\end{array}$ & 20000 & 4015 & 10 & 4015 & 2.0 \\
\hline No fertilizer : & 8200 & 722 & 30 & 23161 & 2.82 \\
\hline $50 \% \mathrm{RDF}$ & 10100 & 1092 & 30 & 32761 & 3.24 \\
\hline 100\% RDF: & 12000 & 1382.5 & 30 & 41475 & 3.45 \\
\hline
\end{tabular}

\section{Conclusion}

Rice grown with $100 \%$ recommended dose of fertilizer plus 10 ton compost /ha produced maximum mean grain yield $4371 \mathrm{~kg} / \mathrm{ha}$ and straw yield $5045.5 \mathrm{~kg} / \mathrm{ha}$ which could be influenced by maximum dry matter production due to the effect of treatments. Application of recommended dose of fertilizer with $10 \mathrm{t}$ compost on preceding rice resulted in maximum seed yield of mustard $(1259 \mathrm{~kg} / \mathrm{ha})$. Mustard grown with recommended dose of fertilizer produced a maximum mean seed yield of $1384 \mathrm{~kg} / \mathrm{ha}$. There was a positive effect of these treatments on seed yield and yield attributes of succeeding mustard. A maximum $\mathrm{BC}$ ratio of 2.0 was obtained for mustard when it was taken after fertilized rice with RDF. The better BC ratio 3.45 was found when mustard was grown with $100 \%$ recommended dose of fertilizer. Farmers are growing mustard in resources scarce condition without following appropriate cropping pattern in terai. To exploit production potential of mustard which is coming up as an emerging seed crop in the country. Hence, farmers are advised to follow proper cropping sequence and nutrient management aspects

\section{References}

Hegde, DM.2003. Integrated nutrient management for oilseeds. National seminar on stress management in oilseeds for attaining self reliance in vegetable oil. Jan. 28-30, 2003. Indian society of oilseed research DoR (ICAR), Rajendranaga, Hydrabad. Pp 221-152.

Hasab, B.1999. Productivity and economics of rice based cropping sequence under mid to high altitude temperate zone of J and K. Indian. J. Agron. 44(1): 36-39.

Sharma, PP and jain NK.2002. Nitrogen requirement of Indian mustard (Brassia jujcea) under different crop sequences. Indian.J. Agric. Sci. 72(2): 101-103.

Singh, J and Singh SP. 2002. Integrated nitrogen management in rice-mustard cropping sequence. In abstracts: National symposium on agriculture in changing global scenario: 206.

Singh, JK; Mishra, PJ; and Singh RA. 1998. Nutrient uptake, moisture use and economics of Indian mustard varieties at rainfed conditions. Environ and Ecol. 16 (1): 54-57. 